\title{
STUDI PERKEMBANGAN ALIRAN KEBATINAN KEROHANIAN SAPTA DARMA DI KABUPATEN MAGETAN TAHUN 1956-2011
}

\author{
Andriawan Bagus Hantoro \& Abraham Nurcahyo*
}

\begin{abstract}
Abstrak
Penelitian ini bertujuan untuk mengetahui perkembangan aliran kebatinan kerohanian Sapta Darma di Kabupaten Magetan Tahun 1956-20011. Penelitian ini merupakan penelitian kualitatif. Pengambilan data menggunakan dua sumber yaitu sumber data primer dari hasil wawancara dengan informan, kemudian sumber data sekunder dari foto dan dokumen yang ada di Persada Kabupaten Magetan yaitu Desa Milangasri. Validasi yang dipergunakan untuk menguji kebenaran data yaitu menggunakan validasi sumber. Menggunakan analisis data model interaktif Miles dan Huberman yang didalamnya terdapat 3 tahapan yaitu melalui proses reduksi data, sajian data dan verifikasi atau proses penarikan kesimpulan.

Sapta Darma telah ada di Kabupaten Magetan sejak tahun 1957. Sapta Darma itu sendiri terjadi melalui wahyu yang di terima oleh Hardjosapoero dari Kediri pada tahun 1956. Selanjutnya Hardjosapoero bergelar Panuntun Agung Sri Gutama dan menyebarkan ajarannya ke seluruh wilayah di Indonesia. Dalam penyebarannya di Kabupaten Magetan, Sri Gutama melakukan peruwatan di beberapa tempat, di antaranya adalah Telaga Sarangan, Air Terjun dan Hargo Dalem Gunung Lawu, dibantu oleh Sri Pawenang dan berhasil menuntun sujud masyarakat Magetan.
\end{abstract}

\section{Kata Kunci : Aliran Kepercayaan, Sapta Darma}

\section{Pendahuluan}

Bentuk peradaban masyarakat sangat beragam. Sejak jaman dahulu hingga kini, telah menjadi bukti setiap perkembangan peradaban selalu diikuti dengan kebudayaan sebagai hasil nyata eksistensi manusia, dimanapun tempatnya berada dalam menjalani kehidupan. Manusia akan senantiasa menemui permasalahan yang menuntut penyelesaian dan jawaban. Upaya-upaya penyelesaian dari permasalahan inilah yang akan menjadi produk kebudayaan suatu individu dalam lingkup sosial masyarakat. Permasalahan kompleks manusia dalam masyarakat akan banyak melahirkan jawaban yang berasal dari pemikiran-pemikiran berdasarkan proses yang tidak sebentar. Permasalahan kehidupan tersebut menyangkut seluruh kehidupan manusia. Tingkah laku manusia untuk mengatasi ragam permasalahan inilah yang disebut kebudayaan. Diungkapkan oleh Taylor dalam Abraham Nurcahyo (2010:6), kebudayaan diartikan sebagai keseluruhan yang mencakup pengetahuan, kepercayaan, seni, moral, hokum, adat, serta kemampuan dan kebiasaan lainnya yang diperoleh manusia sebagai anggota masyarakat. Keragaman permasalahan yang dihadapi manusia dalam perjalanan hidupnya, melahirkan pula keragaman dalam upaya penyelesaiannya. Sedangkan menurut Sutiyono (2010: 40), budaya merupakan suatu sistem ide/ pemikiran. Hal ini disebabkan, budaya dapat mencakup 
sistem ide yang dimiliki bersama, sistem konsep, kaidah-kaidah yang mendasari tata cara kehidupan manusia. Kehidupan manusia terjadi dalam suatu masyarakat. Dalam hidup bermasyarakat tentunya akan banyak sekali perbedaan permasalahan yang ditemui. Untuk itu komunitas memberikan pengaruh yang potensial dalam menentukan cara pandang manusia untuk memahami apa yang dihadapi di lingkungannya. Komunitas dengan akar religiusitas kuat secara laten memberikan kontribusi yang kuat pula dalam membentuk karakter anggotanya dalam memandang kehidupan religi sekitarnya.

Dengan pengetahuan dan dasar pemikiran yang dimiliki oleh suku Jawa ini, banyak sekali cara-cara dan ritual yang dilakukan sebagai cara pemujaan dan bukti bahwa masyarakat Jawa memiliki tingkat kepercayaan yang tinggi terhadap Sang Pemberi Hidup. Ada sebuah konsep pemikiran yang tertanam dalam setiap batin masyarakat Jawa tradisional, bahwa hidup ini berasal dari satu, yaitu Sang Hyang Widi atau Tuhan Yang Maha Esa. Maka bisa dikatakan bahwa kepercayaan masyarakat jawa bersifat monotheisme.

Masyarakat suku Jawa pun menganut ajaran agama resmi yang diakui di Indonesia. Namun tidak menutup kemungkinan, mereka memegang teguh pula budaya leluhur mereka yang telah diwariskan dalam bentuk simbol-simbol, lelaku ataupun pola pandang mereka terhadap cara dan aturan dalam kehidupan terhadap sesama. Keselarasan cara pandang ini banyak memunculkan himpunan aliran kepercayaan yang ada di Pulau Jawa sejak jaman perjuangan hingga kemerdekaan dikumandangkan.

$$
\text { Suwardi Endraswara (2011:15), }
$$
menyatakan bahwa menurut catatan Pengawas Aliran Kepercayaan Masyarakat (PAKEM) Depertemen Agama, jumlah nama aliran Kebatinan pada tahun 1950-an mencapai 400 aliran, baik yang bersifat organisasi maupun perorangan dan kelompok. Menurut catatan terakhir dari sub bagian Kepercayaan dan Tradisi Dinas Kebudayaan DIY tahun 2005, kurang lebih ada 53 paguyuban kebatinan yang masih hidup dan berkembang. Di antara paguyuban tersebut, yang telah berkembang sejak jaman sebelum kemerdekaan yaitu aliran Suci Rahayu (1925), Budha Wisnu (1925), Ilmu Sejati- Prawirosoedarso (1926), Paguyuban Ngesti Tunggal (1932), dan Paguyuban Sumarah (1935). Aliran yang berkembang dan terorganisir secara resmi setelah kemerdekaan yaitu Imam Iqama Haq (IIH), Islam Sejati, Kaweruh Naluri (1949), Sapta Dharma (1952) dan lain-lain.

Sebagai sebuah Himpunan Aliran Kepercayaan, Kerohanian Sapta Dharma sendiri adalah yang termuda di antara banyak aliran penghayat kepercayaan lainnya. Dengan mengutamakan aturan dan tata cara hidup bermasyarakat, yang segalanya diatur dalam wejangan dan kitab 
tersendiri, menjadikan penganutnya berkembang dalam hal jumlah yang tersebar di Pulau Jawa hingga sekarang. Mengalami pasang surut dan kendala yang menarik untuk dikaji sebagai sebuah bentuk eksistensi budaya leluhur khususnya dalam bidang religi atau sistem kepercayaan di tengah minimnya perhatian masyarakat terhadap unsur-unsur kebudayaan sekarang.

Menurut Samsu, seorang tokoh aliran kepercayaan di Magetan, banyak aliran kepercayaan yang berkembang di kabupaten tersebut, namun aliran yang paling banyak diikuti adalah Ilmu Sejati, Suci Rahayu, dan Sapta Darma. Kerohanian Sapta Darma ini, juga diyakini dan berkembang dalam kehidupan sebagian masyarakat Kabupaten Magetan. Di Jalan Tamanasri Dukuh Waru, Desa Milangasri Kecamatan Panekan, terdapat cabang Kerohanian Sapta Darma tempat para pengikut kerohanian ini berkumpul dan mengadakan pertemuan rutin setiap malam Jumat Wage. Seperti masyarakat pada umumnya, penganut Kerohanian Sapta Darma juga menganut agama mayoritas yaitu Islam. Mereka menjalankan ibadah agama masing-masing sekaligus mengamalkan cara sembahyang kerohanian Sapta Darma yang telah dipelajari. Ini tidak jauh berbeda dengan masyarakat Islam Kejawen yang juga telah ada sejak dahulu..

Sekertariat Kerohanian Sapta Darma cabang Magetan yang berada di Desa
Milangasri ini, menjadi semakin menarik karena tidak jauh dari lokasi, juga terdapat sekertariat Lembaga Dakwah Islam Indonesia atau LDII yang bisa dikatakan berseberangan dalam memegang konsep kehidupan beragam. Seperti yang telah diketahui, LDII memegang teguh dan patuh pada syariat Islam, berbeda dengan kerohanian Sapta Darma. Namun Kerohanian Sapta Darma dapat bertahan dan tetap ada di wilayah Kabupaten Magetan.

Melihat fenomena di atas, maka cukup menarik jika kita kupas lebih dalam mengenai perkembangan Kerohanian Sapta Darma di Kabupaten Magetan, dimana masyarakatnya telah tersentuh oleh modernisasi namun tetap mempertahankan kepercayaan leluhur. serta dengan adanya kelompok agama Islam yang cukup kuat dan berdampingan letaknya dengan kelompok Kerohanian Sapta Darma ini. Penelitian ini akan menelaah lebih lanjut dengan mengangkat judul "Perkembangan Aliran Kebatinan Kerohanian Sapta Dharma di Kabupaten Magetan Tahun 1956-2011".

\section{Tujuan dan Manfaat Penelitian}

Tujuan yang hendak dicapai dari penelitian ini adalah untuk

mengetahui perkembangan Aliran Kebatinan Kerohanian SaptaDharma di Kabupaten Magetan. 
Penelitian ini diharapkan dapat bermanfaat sebagai berikut:

a. Sebagai bentuk penelitian sosial budaya masyarakat yang berkaitan dengan aliran kepercayaan khususnya Kerohanian Sapta Darma yang berkembang di Kabupaten Magetan

b. Sebagai sarana pembangunan wawasan, upaya pelestarian unsur budaya khususnya sistem kepercayaan

c. Sebagai sumbangan penelitian lebih lanjut mengenai eksistensi unsur budaya yaitu sistem kepercayaanatau aliran kebatinan yang masih berkembang di tengah masyarakat tingkat eksKaresidenan Madiun.

\section{Kajian Pustaka}

\section{A. Aliran Kebatinan}

Aliran kebatinan jawa telah ada sejak jaman dahulu kala, dilihat dari sejak jaman Panembahan Senapati yang disebut-sebut sebagai seseorang yang melahirkan ajaran kejawen di tanah Jawa. Aliran kebatinan ini bermula dari upaya mendekatkan diri kepada Tuhan Yang Maha Esa. Dalam kamus Al-Munjid Fi Al-Lughati wa Al-A'lam, dikatakan bahwa Tuhan adalah sesuatu yang disembah. Dengan kata lain... setiap yang disembah dan dijadikan sesembahan, maka dia adalah Tuhan ( Hartono Ahmad Jaiz, 2003: 47). Masyarakat Jawa banyak memiliki cara untuk menyembah dan mendekatkan diri pada Tuhannya. Misalnya dengan praktek-praktek mistis yang bersifat magis dan banyak diyakini oleh masyarakat kalangan bawah. Hal itulah yang menjadi pupuk subur yang menumbuhkan aliran kebatinan untuk mendekatkan diri kepada Tuhan. Untuk selanjutnya, banyak khalayak yang menyebut bahwa kebatinan ini masuk dalam aliran kepercayaan.

Ditegaskan oleh Suwardi Endraswara ( 2011:41), bahwa kebatinan Jawa disebut sebagai aliran karena memuat suatu paham yang bervariasi. Keyakinan adalah paham. Aliran kebatinan adalah paham religiusitas kejawen yang memupuk, mempertahankan, dan menghayati aneka doktrin kebatinan. Imam Budhi Santosa (2012: 252), mengatakan bahwa kejawen bukan agama sebagaimana tolak ukur yang digunakan oleh agama samawi, yaitu nilai ajaran yang diperoleh dari berdasarkan wahyu yang disampaikan Allah SWT kepada para nabi dan rasul. Sekalipun begitu, ada kesamaan antara kejawen dengan agama-agama yang ada yaitu mengenai mistisme. Diantara keduanya tercampur dengan budaya mistik yang sukar diraba dengan nalar dan logika walau dalam bentuk yang berbeda. Huston Smith, (terjemahan Safroedin Bahar, 2001:121) menyebutkan bahwa agama selalu tercampur dengan magis, mistisisme dan mukjizat; dengan ilmu sihir, hal yang eksoterik dan yang menakutkan; dengan hal-hal seperti spiritualisme dan adikodrati.

Kejawen lebih mendekati bentukbentuk filsafat yang khas Jawa. Kebatinan Jawa tidak lain adalah suatu aliran 
kepercayaan yang diyakini, ditaati, dipuji, dan dieksplorasi dalam kehidupan untuk menemukan ketentraman hidup. Tidak dapat dipungkiri, bahwa ajaran spiritualisme jawa banyak mengacu pada filosofi pewayangan dan karya sastra yang terkait dengannya. Misalnya dari kitab Mahabarata, kitab Ramayana, Serat Pramayoga, Serat Arjunawiwaha, Serat Purwakhanda, Serat Pustaka Raja Purwa. Umumnya persebarannya melalui pergelaran wayang, Imam Budhi Santosa ( 2012: 253).

\section{B. Sapta Darma}

Imam Budhi Santosa (2012:149), menyebutkan bahwa Sapta Darma didirikan tahun 1955 oleh guru agama bernama Hardjosapoero yang kemudian mengganti namanya menjadi Panuntun Agung Sri Gutomo. Beliau berasal dari Desa Keplakan, Pare, Kediri, Jawa Timur. Hardjosapoero meninggal pada 16 Desember 1964. Selanjutnya pusat pimpinan Sapta Darma dipindahkan ke Yogyakarta. Setelah Panuntun Agung Sri Gutomo meninggal dunia kepemimpinan digantikan oleh Panuntun Agung Sri Pawenang, yakni seorang wanita bernama Sri Suwartini, salah satu lulusan Universitas Gajah Mada. Semenjak kepemimpinan Sapta Darma dipimpin oleh Sri Pawenang, perkembangan Sapta Darma semakin meningkat.

Sapta Darma kebanyakan beranggotakan orang-orang pedesaan dan para pekerja kasar di kota. Ajaran Sapta
Darma adalah termasuk aliran kebatinan yang sederhana, oleh karena itu ajaran tentang Allah sangat singkat sekali. Allah di dalam ajaran Sapta Darma ini disebut Yang Mahakuasa atau Allah atau Sang Hyang Widi. Allah itu adalah Zat yang Mutlak, dalam arti yang mendasar Allah adalah Zat yang bebas dari segala hubungan sebab akibat, Dia adalah Mutlak, sumber segala sebab akibat. .... bahwa sesungguhnya Allah Hyang Maha Kuasa itu ada dan tunggal. Dan memiliki lima sila (sifat dan sikap perwujudan kehendak) yang mutlak yaitu "MAHA AGUNG, MAHA ROKHIM, MAHA ADIL, MAHA WASESA, DAN MAHA LANGGENG, (Sri Pawenang dkk, 2010: 163). Kelima sifat Allah tersebut disebut Pancasila Allah dalam aliran Sapta Darma ini.

Dalam kitab Wewarah Ajaran Sapta Darma, dijelaskan bahwa Sujud adalah tata cara menyembah Allah Hyang Maha Kuasa, dan dilaksanakan minimal sekali dalam sehari. Racut adalah peribadatan yang kontroversial dalam ajaran Sapta Darma, didalam pelaksanaannya berarti memisahkan rasa dengan perasaan (pangrasa: Jawa), dengan tujuan menyatukan diri dengan Sinar Sentral atau roh Suci bersatu dengan Sinar Sentral (Sri Pawenang dkk, 2010: 169). Ini berarti pada waktu Racut dapat digunakan menghadapkan Hyang Maha/ Suci Roh Suci manusia ke hadapan Hyang Maha Kuasa dan bertemu secara langsung. Sedangkan Ening atau hening, adalah sebuah cara 
pengosongan pikiran dari sifat keduniawian dan pasrah terhadap alur hidup sesuai kehendak sang Hyang. Dan yang terakhir Olah Rasa, adalah proses relaksasi jasmani untuk meningkatkan konsentrasi dalam menjalani kehidupan. Sujud dan Racut merupakan sembahyang wajib, sedangkan Ening dan Olah Rasa adalah ibadah yang merupakan pelengkap dalam keseharian para pemeluk ajaran Sapta Darma.

Para pengikut Sapta Darma pun memiliki tempat peribadahan sendiri yang disebut Sanggar. Di setiap sanggar ada seorang tuntunan yang ditunjuk sebagai pemimpin dan bertanggung jawab membina spiritualitas warga sanggar tersebut. Dalam Sapta Darma ada dua jenis sanggar, yaitu "Sanggar Candi Sapto Renggo" hanya ada satu di Yogyakarta, sebagai pusat kegiatan kerohanian Sapta Darma dan "Sanggar Candi Busono" yang tersebar di daerahdaerah, Imam Budhi Santosa (2012: 153). Sanggar Candi Busono ini biasanya berada dalam wilayah atau cabang-cabang yang disebut dengan Persada.

\section{Metode Penelitian}

Penelitian ini dilaksanakan di Desa Milangasri, Kecamatan Panekan, Kabupaten Magetan. Ditinjau dari aspek sosial budaya dan kehidupan sehari-harinya masyarakat Desa Milangasri kehidupan masyarakat sudah bisa dikatakan semi modern karena walaupun wilayahnya berupa desa, namun mengalami perubahan sosial setelah adanya
Ringroad untuk akses menuju obyek wisata Telaga Sarangan, juga karena berdekatan dengan Terminal Magetan.

Seperti halnya dengan ciri khas desa pada umumnya, wilayah Desa Milangasri terdiri atas lahan pertanian atau persawahan dan permukiman dengan penduduk sebagian besar bermata pencaharian sebagai petani. Desa Milangasri merupakan bagian dari Kecamatan Panekan yang berada di sebelah utara Kabupaten Magetan.

Data primer dalam penelitian ini diperoleh dari hasil wawancara dengan para informan, diantaranya dengan pemerintahan kecamatan dan desa, ketua Persada Kerohanian Sapta Darma, beberapa pengikut Sapta Darma, serta masyarakat sekitar desa Milangasri. Sumber data sekunder adalah data yang diperoleh dari beberapa informasi berupa dokumentasi termasuk arsip-arsip lembaga yang berkaitan dengan masalah dalam penelitian, Husaini Usman (dalam Jurnal Agastya 2012: 64). Sumber data sekunder bisa berasal dari data pustaka serta foto-foto yang terkait sebagai penunjang dari data primer.

Dalam penelitian ini, trianggulasi yang dipergunakan adalah trianggulasi data atau disebut juga trianggulasi sumber. H.B Sutopo (2002: 79), menyebutkan bahwa trianggulasi sumber bisa menggunakan satu jenis sumber data seperti misalnya informan, namun beberapa informan atau narasumber yang digunakan harus 
merupakan kelompok atau tingkatan yang berbeda-beda. Dalam arti penekanannya bukan pada teknik pengumpulan data, melainkan pada perbedaan sumber data.

Secara singkat teknik triangulasi sumber dapat dilihat dari bagan di bawah ini:

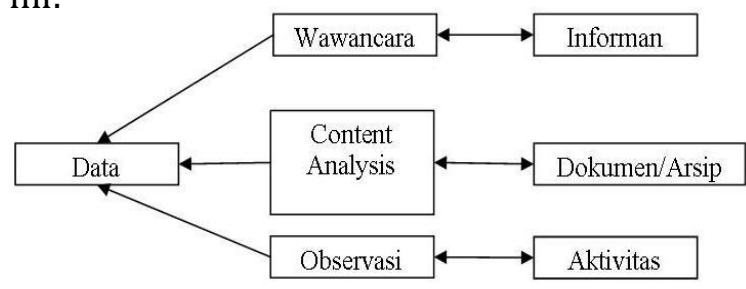

Bagan 3.2 Trianggulasi sumber (H.B Sutopo,2002:80)

Adapun secara garis besar proses analisis data dapat dilihat pada bagan di bawah ini:

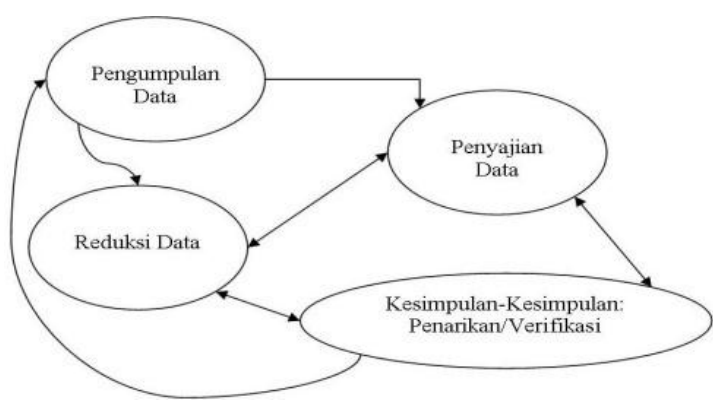

Bagan 3.3. Analisis Kualitatif Model Interaktif Miles dan Huberman (dalam H.B. Sutopo, 2002:96).

\section{Hasil Penelitian}

\section{A. Sejarah Penerimaan Wahyu Wewarah Sapta Darma \\ Awal mula turunnya wahyu Sapta}

Darma bermula dari kehidupan seorang laki-laki yang bernama Soeporo yang dilahirkan pada tanggal 27 Desember 1914 di Desa Pare, Kecamatan Pare, Kabupaten
Kediri Jawa Timur. Soeporo merupakan putra sulung dari dua bersaudara pasangan Bapak Soehardjo dan Ibu Soelijah. Semasa hidupnya, Soeporo menempuh pendidikan Sekolah Dasar dan tinggal diasuh oleh kakek dan ibunya karena bapaknya meninggal sejak usia satu tahun. Soeporo remaja juga aktif dalam organiasasi dan perkumpulan pemuda pada waktu itu. yaitu sebagai Anggota Kepanduan Surya Wirawan tahun 1937. Turut pula aktif dalam keanggotaan PARINDRA di Pare, Kediri. Pada tahun 1945 ikut pula menjadi bagian dari PARTINDO, dan juga aktif dalam perjuangan mempertahankan kemerdekaan Indonesia dengan di dalam Laskar Perjuangan pada tahun 1947 sampai 1949. Sopoero menikah pada usia 25 tahun dengan Sarijem, dan berganti nama menjadi Hardjosapoero dan dikaruniai 7 putra. Hardjosapoero bekerja sebagai tukang cukur disamping pula berdagang kecil-kecilan untuk mencukupi kebutuhan hidupnya, (Wawancara dengan Samsu, Tanggal 5 Mei 2013).

\section{Penerimaan Wahyu Sujud}

Penerimaan wahyu oleh Bapak Hardjosapoero terjadi secara bertahap. Pertama kali terjadi pada tanggal 26 Desember 1952 malam, secara sadar Bapak Hardjosapoero digerakkan oleh kekuatan tidak nampak sehingga terbangun dari tidurnya. Tanpa bisa menguasai diri, beliau duduk dalam posisi bersila dan bersedekap mengahadap ke arah timur. Sekalipun berusaha melawan, namun tanpa bisa di 
kontrol tubuhnya tetap melaksanakan sujud. Di luar kemauannya, beliau meneriakkan lafal berbahasa Jawa dengan keras, yang berbunyi:

" Allah Hyang Maha Agung

Allah Hyang Maha Rakhim

Allah Hyang Maha Adil."

Dalam keadaan bergetar hebat, dengan bersila secara serta merta badan beliau membungkuk namun tetap dalam keadaan bersila dan bersedekap hingga dahi menyentuh lantai, meneriakkan kalimat dalam bahasa Jawa:

"Hyang Maha Suci Sujud Hyang Maha Kuwasa Kuwasa

Hyangmaha Suci Sujud Hyang Maha

Hyang Maha Suci Sujud Hyang Maha Kuwasa."

Gerakan tersebut kembali dalam

posisi duduk kemudian sujud kembali hingga dahi menyentuh lantai sambil berkata:

"Kesalahane Hyang Maha Suci Kuwasa

Nyuwun Ngapura Hyang Maha

Kesalahane Hyang Maha Suci

Nyuwun Ngapura Hyang Maha Kuwasa

Kesalahane Hyang Maha Suci

Nyuwun Ngapura Hyang Maha Kuwasa."

Kemudian duduk kembali, dan mengulangi sujud ketiga kalinya hingga dahi menyentuh lantai sambil mengucap:

"Hyang Maha Suci Mertobat Hyang Maha Kuwasa, Hyang Maha Suci Mertobat Hyang Maha Kuwasa, Hyang Maha Suci Mertobat Hyang Maha Kuwasa."

Gerak sujud menyembah kepada Hyang Maha Kuasa tersebut dituntun secara langsung oleh Hyang Maha Kuasa, dan wahyu sujud ini turun pada hari Jumat Wage pukul 01.00 WIB sampai dengan pukul 05.00 WIB.

Kejadian aneh dan luar biasa ini kemudian di ceritakan Hardjosapoero kepada keluarga dan teman-temannya yaitu Bapak Djojodjaimoen, Bapak Kemi Handini, dan Bapak Somogiman. Malam berikutnya, keempat orang tersebut juga digerakkan oleh suatu kekuatan untuk melakukan sujud. Setelah kejadian ini, mulai tersiar kabar dari mulut ke mulut perihal wahyu yang diterima oleh Hardjosapoero beserta teman-temannya. Peristiwa berikutnya merupakan wahyu peribadatan lebih tinggi yang diterima oleh Hardjosapoero yaitu wahyu Racut atau yang disebut "Mati Sajroning Urip".

\section{Penerimaan Wahyu Racut}

Racut ini disaksikan teman-teman Hardjosapoero yang ditambah oleh dua orang yaitu Bapak Darmo dan Bapak Rekso Kasirin. Adapun Racut itu sendiri merupakan pengalaman spiritual Hardjosapoero dalam kondisi berbaring kearah timur, dalam keadaan mati. Menurut kesaksian teman-temannya,Hardjosapoero berbaring dalam posisi seperti orang mati bersedekap, tanpa bernafas selama hampir setengah jam kemudian bangun dan menceritakan pengalamannya selama beberapa waktu tersebut.

Dalam kisahnya selama Racut, Hardjosapoero merasakan rohaninya di bawa ke sebuah tempat yang sangat indah 
oleh sesosok sinar terang hingga berada pada dua buah sumur berair jernih yang bernama Sumur Jalatunda dan Sumur Gumuling. Ruh Hardjosapoero mendapatkan pula pengalaman di beri dua buah keris dengan Warangka atau sarung keris bercorak Mataraman yang disebut sebagai Keris Nogososro dan Keris Bendo Segodo. (Wawancara dengan Samsu tanggal 5 Mei 2012)

\section{Penerimaan Wahyu Simbol Pribadi Manusia, Wewarah Pitu dan Sesanti}

Wahyu Simbol Pribadi Manusia ini terjadi pada tanggal 12 Juli 1954 dengan disaksikan oleh teman-teman Hardjosapoero. Simbol Pribadi Manusia ini berupa tulisan bersinar berbunyi Sapta Darma dan tulisan Nafsu, Budi, Pakarti yang semuanya menggunakan huruf Jawa. Sedangkan Wewarah Pitu adalah tujuh ajaran pokok yang turun dalam wujud kalimat dalam huruf Jawa bersinar yang berjatuhan dan berbunyi:

Setya Tuhu Marang Ananing Pancasila

Kanthi Jujur Lan Sucining Ati, Kudu Setya Anindaake Angger-Angger Ing Negarane

Melu Cawe-Cawe Acancut Tali Wanda Njaga Adeging Nusa Lan Bangsane

Tetulung Marang Sapa Bae Yen Perlu, Kanthi Ora Nduweni Pamrih Apa Bae, Kajaba Mung Rasa Welas Lan Asih

Wani Urip Kanthi Kapitayan Saka Kekuwatane Dhewe

Tanduke Marang Warga Bebrayan Kudu Susila Kanthi Alusing Budi Pakarti, Tansah Agawe Pepadhang Lan Mareming Liyan

Yakin Yen Kahanan Donya Iku Ora Langgeng, Tansah Owah Gingsir (Anyakra Manggilingan).
Kalimat-kalimat tersebut seterusnya menjadi acuan ajaran Sapta Darma dan pedoman hidup para penganut ajaran Sapta Darma. Sedangkan sesanti atau semboyan Sapta Darma berbunyi, " Ing ngendi bae, marang sapa bae Warga Sapta Darma kudu sumunar pindha baskara”, yang artinya adalah " Di manapun, dengan siapa saja Warga Sapta Darma harus bisa bersinar laksana pancaran matahari". Ini menyiratkan sebuah makana bahwasanya penganut ajaran Sapta Darma harus bisa menjadi panutan bagi siapapun, menolong dan memperlakukan sesama manusia tanpa membeda-bedakan, (Wawancara dengan Supadi, Tanggal 6 Mei 2013).

\section{Penerimaan Wahyu Istilah Tuntunan dan Istilah Sanggar}

Penerimaan Wahyu ini berawal dalam suatu persujudan bersama di rumah Hardjosoeporo pada tanggal 15 Oktober 1954. Wahyu tersebut memerintahkan agar menunjuk Bapak Parto Sarpan sebagai Tuntunan Sanggar pare, Kediri. Sejak itulah mulai dikenal istilah tuntunan, sebagai orang yang menuntun sujud bagi calon warga Sapta Darma. sesangkan Sanggar adalah tempat persujudan bersama atau tempat ibadah warga Sapta Darma.

\section{Penerimaan Wahyu Saudara Dua Belas \\ Tepat dua tahun setelah} penerimaan wahyu sujud, pada tanggal 27 Desember 1954 setelah pelaksanaan sujud bersama kembali turun wahyu baru. Wahyu ini turun melalui gerakan yang berawal dari 
penyatuan dua telapak tangan di dada, mengarah ke ubun-ubun, dahi, pundak kiri, pundak kanan, dada kiri, dada tengah, dada kanan, berlanjut ke arah pusar, lambung kiri, lambung kanan, ke arah tulang ekor, kemudian menyatukan telapak tangan dan ujung-ujung jari kembali di depan dada.

Dalam kedua belas titik tersebut terdapat nama simbol tersendiri yang mewakili getaran pribadi manusia. Secara berurutan nama-nama tersebut yaitu Hyang Maha Suci, Premana, Jati Ngarang, Nagatahun, Gandarwaraja, Endra, Brama, Bayu, Mayangkara, Sukmarasa, Sukmakencana, dan Bagindakilir. Pusat kesucian getaran pribadi manusia berada pada Hyang Maha Suci, yaitu titik di dada.

\section{Penerimaan Wahyu Tali Rasa dan Wasiat Tigapuluh Tiga}

Simbol tali rasa merupakan merupakan 20 titik tali rasa atau sentral dari penyembuhan dalam diri manusia. Dilambangkan dengan abjad Jawa yaitu $H a$ Na Ca Ra Ka Da Ta Sa Wa La Pa Da Ja Ya Nya Ma $\mathrm{Ga} \quad \mathrm{Ba}$ Tha Nga. Setiap abjad melambangkan titik yang meliputi sekujur tubuh manusia dari atas kepala hingga ujung kaki. Jika telah mengetahui 20 titik tersebut, maka akan sangat membantu dalam upaya penyembuhan berbagai macam penyakit dengan teknik Sabda Usada Waras.

Wasiat Tigapuluh Tiga, adalah ajaran pelengkap Sapta Darma yang merupakan wejangan sarat makna. Wasiat ini bersifat tertutup dan isinya hanya sebatas diketahui oleh pengikut sapta Darma. Namun nama-nama wejangan tersebut masih bisa diketahui yaitu, Sapu jagad, Kucing Putih, Jeruk Purut, Payung Suci, Kembang jayakusuma, Singa Barong, Mustikaning Manik, Rembulan, Wit Waringin, Jaran Sembrani, Upase Nagatahun, Mliwis Putih, Piring Kencana, Mangkok Kencana, Cupu Kencana, Topeng Kencana, Tropong Kencana, Kaca Kencana, Kurungan Kencana, Kidang Kencana, Sarine Angin, Sarine Geni, Sarine Banyu, Sarine Pangan, Bala Srewu, Candhabirawa, Patidur lan Kasur, Barisan Ula, Barisan Banaspati, Barisan Kethek, Barisan Uler, Barisan Setan, dan Bantal lan Guling.

\section{Penerimaan Wahyu Nama Sri Gutama dan Agama Sapta Darma}

Sebelum penerimaan wahyu nama

Sri Gutama, gelar Hardjosoeporo adalah Resi Brahma, Resi Brahmana dan lain-lain. Wahyu gelar Sri Gutama ini terjadi melalui terlihatnya pancaran tulisan tanpa media yang disebut Sastra Jendra Hayuningrat. Di dalam tulisan tersebut merupakan wahyu bahwa gelar terakhir beliau menjadi Sri Gutama Panuntun Agung.

Wahyu agama Sapta Darma merupakan arti khusus dari tiga abjad Jawa yaitu $\mathrm{Ha}, \mathrm{Ga}$, dan Ma. Abjad $\mathrm{Ha}$ atau berbunyi A memiliki arti sebagai asal muasal manusia. Ga yaitu Gama atau Kama yang berarti air suci. Ma yaitu Maya atau Sinar Cahaya Allah. Dengan adanya wahyu 
tersebut maka nama Sapta Darma menjadi lengkapnya adalah Agama Sapta Darma, (Wawancara dengan Samsu, 5 Mei 2013).

\section{B. Sekilas Perjalanan Panuntun Agung Sri Gutama}

Setelah wahyu Sapta Darma tersebut turun hingga tahun 1956, Hardjosapoero mendapatkan gelar baru yaitu Panuntun Agung Sri Gutama dan menjalankan tugas menyebarkan ajaran Sapta Darma ke seluruh Indonesia. Dalam perjalanan penyebaran ini Panuntun Agung Sri Gutama melintasi hampir seluruh penjuru pulau di Nusantara, dan dalam wilayah yang disinggahinya selalu berhasil memiliki pengikut baru, (Wawancara dengan Samsu, Tanggal 5 Mei 2013).

Selama masa penyebaran ajaran Sapta Darma, Panuntun Agung Sri Gutama menggunakan empat cara, yaitu:

a. Melakukan ritual peruwatan di tempattempat yang dikeramatkan oleh masyarakat. Tujuan ruwatan ini adalah untuk mensucikan suatu tempat dari roh-roh jahat, jin, ataupun makhluk halus lainnya agar tidak tersesat dan mengganggu manusia. Disamping itu juga untuk mencegah agar tempattempat tersebut tidak dijadikan sarana pemujaan yang berwujud animisme ataupun dinamisme.

b. Memberikan pertolongan berupa penyembuhan segala macam penyakit kepada siapa saja dengan jalan Tuhan,, yang dikenal dengan Sabda Usada
Waras. Hanya dengan mengucapkan kata "Waras" yang berarti sembuh, maka si penderita sakit dapat disembuhkan.

c. Menuntuni sujud bagi siapa saja yang berminat menghayati ajaran Sapta Darma.

d. Melakukan mukjizat atau keistimewaan yang sulit dinalar akal manusia.

Selama masa penyebarannya, Panuntun Agung Sri Gutama di dampingi oleh Soewartini Martodihardjo, S.H yang bergelar Panuntun Wanita Sri Pawenang. Soewartini ini nantinya akan menggantikan peran Sri Gutama smenyebarkan Sapta Darma setelah Sri Gutama meninggal. ( Wawancara dengan Darno, Tanggal 7 Mei 2013).

\section{Perkembangan Ajaran Kerohanian Sapta Darma di Wilayah Kabupaten Magetan}

Di dalam penyebaran ajaran Sapta Darma yang di lakukan oleh Panuntun Agung Sri Gutama dan Sri Pawenang, wilayah Kabupaten Magetan pun juga menjadi tempat dan tujuan. Dalam catatan perjalanan, beliau sampai di Kabupaten Magetan pertama kali di daerah Maospati pada tanggal 4 Februari 1957. Ketika sampai di kabupaten tersebut, beliau berhasil mengajak masyarakat Magetan untuk melaksanakan perintah sujud hampir 50 orang. Ajakan tersebut diikuti dengan melakukan penyembuhan kepada beberapa orang yang menderita sakit dengan Sabda 
Usada Waras. Sri Gutama berada selama sepuluh hari, yaitu terhitung mulai tanggal 4 Februari 1957 sampai dengan 14 Februari 1957, sebelum akhirnya pergi ke daerah Randublatung Blora pada tanggal 15 Februari 1957.

Pada tanggal 23-24 April 1957, Sri Gutama kembali lagi ke Magetan dan melakukan ritual peruwatan di beberapa tempat, diantaranya adalah di Sarangan, Argodalem, Telaga Pasir, dan Air Terjun. Dalam acara peruwatan, Sri Gutama melakukan ritual pengusiran jin dan rohroh jahat dengan tujuan untuk menghindarkan agar orang-orang di sekitar wilayah tersebut tidak menganggap itu sebagai tempat yang keramat. Hal tersebut memang bertentangan dengan ajaran Sapta Darma, tidak perlu menganggap suatu tempat sebagai tempat sakral dan diberi sesaji, para pemeluk ajaran Sapta Darma hanya memohon rizki, keselamatan, dan perlindungan hanya kepada Allah Hyang Maha Kuasa. (Wawancara dengan Supadi Tanggal 6 Mei 2013).

Sapta Darma adalah ajaran ketuhanan yang melarang pemeluknya untuk menyembah selain Allah Hyang Maha Kuasa. Karena itu dalam prakteknya, tidak ada upaya melakukan praktek untuk menyekutukan sang Pencipta dengan sesajen ataupun ritualitas mistik lainnya. Peruwatan pada dasarnya hanyalah upaya pencegahan agar suatu tempat tidak disakralkan oleh masyarakat setempat. (Wawancara dengan Samsu, 5 Mei 2013)

$$
\text { Perjalanan Panuntun Agung Sri }
$$

Gutama terus berlanjut di beberapa wilayah, namun beliau kembali lagi ke Kabupaten Magetan setahun kemudian tepatnya 4 Februari 1958. Ajakan sujud kepada masyarakat Magetan kembali membuahkan hasil, dalam persinggahan tersebut pemeluk ajaran Sapta Darma menjadi sekitar 200 orang. Sri Gutama berada di Magetan selama 20 hari dan melanjutkan jalur persebarannya ke wilayah lainnya, (Wawancara dengan Samsu, Tanggal 5 Mei 2013).

Dalam persebarannya di Kabupaten Magetan, Panuntun Agung Sri Gutama didampingi oleh Panuntun Wanita Sri Pawenang dan beberapa orang. Pemeluk ajaran Sapta Darma yang berhasil diajak untuk melakukan sujud adalah golongan orang-orang petani, pekerja kasar, atau lapisan masyarakat kelas menengah ke bawah. Hal tersebut dikarenakan hampir sebagian para pengikut Sapta Darma mau melaksanakan sujud setelah disembuhkan dari sakit oleh Panuntun Agung Sri Gutama ataupun Sri Pawenang. Sakit tersebut tidak bisa disembuhkan karena keterbatasan ekonomi sehingga mereka bersedia melaksanakan apapun asalkan bisa disembuhkan. Dengan metode Sabda Usada Waras, para penderita sakit ini melaksanakan sujud dan memohon kesembuhan kepada Allah Hyang Maha 
Kuasa. Setelah itu Panuntun Agung Sri Gutama mengucapkan kata Waras kepada penderita sakit. Dan karena karunia Tuhan, sebagian besar orang-orang berhasil disembuhkan dari penyakitnya. (Wawancara dengan Samsu, 5 Mei 2013).

Upaya yang dilakukan Sri Gutama untuk menarik perhatian masyarakat terhadap Sapta Darma adalah dengan jalan penyembuhan dan ruwatan di suatu wilayah. Upayanya kebanyakan berhasil setelah hampir sebagian masyarakat lapisan bawah disembuhkan dari penyakit ringan ataupun yang tergolong berat dan tidak terdeteksi oleh medis. Dengan cara itulah ajaran Sapta Darma diterima oleh masyarakat dan menjadikan Sri Gutama terkenal karena metode Sabda Usada Waras. (Wawancara dengan Supadi, 6 Mei 2013)

Karena bukti kesembuhan itulah, orang-orang mengakui bahwa Sapta Darma adalah ajaran yang bisa memberikan bukti nyata sehingga mereka memeluk ajaran Sapta Darma. Selama periode tahun awal Panuntun Agung Sri Gutama menginjakkan tanah Magetan hingga sekarang, pemeluk ajaran Sapta Darma di wilayah ini sudah mengalami perkembangan hingga ribuan orang. Jumlah ini merupakan pemeluk taat ajaran Sapta Darma, ataupun yang hanya menjadi anggota saja. (Wawancara dengan Darno, Tanggal 7 Mei 2013).

Pemeluk Sapta Darma di Kabupaten Magetan sekarang telah mencapai ribuan orang. Jumlah tersebut hanya berdasarkan perkiraan karena bagi Sapta Darma, perhitungan angka bukanlah hal utama. Lebih diutamakan mengenai ketaatan dalam menjalankan ajaran. Kesungguhan menjalankan ajaran akan terlihat dengan bagaimana praktek keseharian hidup manusia itu sendiri. Karena itu, banyak pemeluk Sapta Darma yang tidak mengikuti petemuan rutin namun tetap berhubungan dengan pemeluk lainnya dalam kesempatan yang lainnya. Pertemuan rutin Jumat Wage hanyalah salah satu cara pemersatu warga dan bukanlah suatu keharusan yang sifatnya memaksa. (Wawancara dengan Samsu, 5 Mei 2013).

\section{Pembahasan}

Sebagai sebuah dogma kebatinan, sejak awal penerimaan wahyu sujud oleh Hardjosoeporo Sapta Darma telah berkembang di seluruh penjuru nusantara. Sapta Darma adalah satu dari ratusan aliran kebatinan yang berpangkal dari kearifan kebudayaan Jawa yang masih eksis dan semakin kuat perkembangannya dari awal hingga sekarang. Ini tidak bisa dilepaskan dari upaya para pendahulunya dalam menyebarkan ajaran tersebut. Sebagai sebuah produk kebudayaan yang berwujud sistem kepercayaan atau religi, manusia akan senantiasa mengalami pembaharuan dala hal kepercayaan terhadap sang pemberi kekuatan, Tuhan Yang Maha Kuasa. Hal ini merupakan suatu bukti bahwa manusia senantiasa membutuhkan 
penguatan baru untuk memuaskan pengalaman religiusitas mereka selama hidup. Satu saja tidak cukup, karena itulah Sapta Darma bisa berkembang hingga sekarang.

\section{a) Kerohanian Sapta Darma Berbeda dengan Ritualitas Kejawen}

Suatu hal yang mencengangkan, bahwa penganut ajaran Sapta Darma dengan yakin mengatakan bahwa yang mereka anut bukanlah kejawen. Agak sukar dipastikan memang, namun pernyataan tersebut diperkuat dengan ritualitas yang mereka lakukan. Sapta Darma tidak pernah mengajarkan cara-cara animisme apapun kepada para pemeluknya. Dalam tuntunan ibadah pun, mereka hanya menyembah Tuhan yang mereka kenal dengan sebutan Pancasila Allah, yaitu Allah Hyang Maha Agung, Allah Hyang Maha Rokhim (Maha Pengasih), Allah Hyang Maha Adil, Allah Hyang Maha Wasesa (Penguasa Semesta), dan Allah Hyang Maha Langgeng.

Kelima nama tadi hanyalah panggilan atau sebutan yang merujuk pada satu pusat kehidupan, yaitu Tuhan Yang Maha Esa. Itu sebabnya apabila warga Sapta Darma menghayati benar ajaran, mereka hanya beribadah dengan sesuai tuntunan, yaitu Sujud, Racut, dan Olah Rasa. Ritualitas bukti ketaatan terhadap Allah tidak diwujudkan dengan upacara sesaji, pemujaan tempat keramat ataupun yang lainnya. Berbeda dengan paham kejawen yang sedemikian mempercayai tempat-tempat keramat dan mensakralkan benda-benda yang dianggap memiliki kekuatan gaib.

\section{b) Sapta Darma adalah Agama yang Berdiri Sendiri}

Sesuai dengan wahyu yang di terima oleh Sri Gutama, sapta Darma adalah ajaran agama. Tidak mengacu pada ajaran agama lainnya seperti Islam yang terbagi dalam beberapa aliran, agama Kristiani yang terbagi menjadi dua, ataupun aliran Hinayana dan Mahayana dalam agama Buddha. Sapta Darma berbeda dan muncul sebagai sebuah agama sebagaimana wahyu baru yang diterima. Buah ilham dan ajaran Sri Panuntun Gutama dikumpulkan dan dibukukan sehingga menjadi kitab suci yang disebut "Wewarah Agama Sapta Darma" (Hilman Hadikusuma, 1983: 114). Jika sekarang kita tidak menemukan kata sebutan agama dalam resmi Sapta Darma, itu karena hasil dari upaya Sri Pawenang untuk menghindari konflik antar agama. Dengan menggantinya menjadi Kerohanian sesuai dengan Penetapan Presiden Nomor 1 Tahun 1965, tentang Pencegahan Penyalahgunaan dan atau Penodaan Agama.

Sri Pawenang dkk (2010: 200), menyebutkan dalam Rapat Tuntunan seluruh Indonesia tanggal 26-27 Desember 1966 telah digariskan oleh Ibu Sri Pawenang, bahwa untuk menyelamatkan ajaran Agama Sapta Darma, akibat adanya PENPRES Nomor 1 Tahun 1965 tersebut, maka Agama Sapta Darma harus menyesuaikan diri dengan mengubah nama 
menjadi "KEROKHANIAN SAPTA DARMA",. Sekalipun begitu, pergantian nama tersebut tidak mengurangi makna ajaran Sapta Darma karena segala aktivitasnya telah mendapatkan legitimasi dari Kejaksaan Agung pada tanggal 8 April 1972.

c) Sapta Darma Mengajarkan Toleransi Serta Kesatuan Bangsa dan Negara

Sebagai sebuah ajaran kerohanian, Sapta Darma mengajarkan kepada para pemeluknya bagaimana cara mendekatkan diri terhadap Tuhan. Di samping ada tuntunan ibadah wajib yaitu Sujud minimal dua kali dalam sehari serta Racut, ada lagi ajaran yang menjelaskan tentang ibadah tanpa tuntunan. Ini adalah ibadah terhadap sesama, yaitu saling tolong menolong dalam kebaikan kepada siapapun manusia. Tidak memandang golongan, agama ataupun status sosial yang lainnya. Hal tersebut merupakan poin tersendiri bagi pemeluk Sapta Darma dalam upaya menegakkan Sesanti Sapta Darma.

Tujuan peruwatan yang dilakukan oleh Sri Gutama bukanlah untuk animisme ataupun dinamisme. Itu hanyalah sebuah cara peribadatan terhadap sesama makhluk Allah, serta untuk mendoakan para pendahulunya, roh-roh ataupun jin makhluk Allah untuk senantiasa menyembah Allah Hyang Maha Kuasa dan tidak menggoyahkan iman manusia pemeluk ajaran agama apapun.

Sapta Darma bukanlah aliran sesat yang menyimpang dari peraturan undang- undang Negara Indonesia. Sejak awal-awal penyebaran oleh Sri Gutama maupun Sri Pawenang, Sapta Darma telah mendapatkan pengesahan dari Kejaksaan Agung Republik Indonesia tentang perlindungan seluruh aktivitas yang dijalankannya. Pengesahan tersebut didapat setelah menimbang bahwa kegiatan yang dilakukan bukanlah kegiatan yang bertujuan untuk menimbulkan konflik umat beragama ataupun menggoyahkan kesatuan suatu negara. Justru dalam aktivitasnya bertujuan untuk mendidik rohani manusia untuk meningkatkan keimanan terhadap agama yang dianut, serta mendidik warga negara untuk setia dan menjunjung tinggi persatuan berasaskan Pancasila.

Pengorganisasian Sapta Darma di lakukan oleh Sri Pawenang sesuai PENPRES Nomor 1 Tahun 1965 tentang Pencegahan Penyalahgunaan dan/ atau Penodaan Agama, setelah memperhatikan bahwa ajaran ini telah mulai banyak dianut oleh masyarakat. Tujuannya adalah untuk mengatur agar warga Sapta Darma memiliki prospek yang jelas terhadap keyakinannya. Di bentuknya Persada cabang Propinsi, cabang Kabupaten dengan ketua serta Tuntunan Persada ini sebagai sebuah upaya perlindungan ajaran serta persebaran Sapta Darma.

\section{A. Perkembangan Aliran Kebatinan Kerohanian Sapta Darma Cabang Kabupaten Magetan \\ 1. Periodesasi Perkembangan}




\section{a) Masa Tahun 1957-1966}

Perkembangan Sapta Darma di kabupaten Magetan berawal dari tahun kedatangan Sri Gutama. Dalam catatan perjalanan, beliau sampai di Kabupaten Magetan pertama kali di wilayah Maospatipada tanggal 4 Februari 1957. Pada masa itu, beliau berhasil mengajak masyarakat Magetan untuk melaksanakan perintah sujud hampir 50 orang. Ajakan tersebut diikuti dengan melakukan penyembuhan kepada beberapa orang yang menderita sakit dengan Sabda Usada Waras. Beliau berada di Kabupaten Magetan selama sepuluh hari, yaitu terhitung mulai tanggal 4 Februari 1957 sampai dengan 14 Februari 1957, sebelum akhirnya pergi ke daerah Randublatung pada tanggal 15 Februari 1957.

Pada tanggal 23-24 April 1957, Sri Gutama kembali lagi ke Magetan dan melakukan ritual peruwatan di beberapa tempat. Diantaranya adalah di Sarangan, Argodalem, Telaga Pasir, dan Air Terjun. Dalam acara peruwatan, Sri Gutama melakukan ritual pengusiran jin dan rohroh jahat dengan tujuan untuk menghindarkan agar orang-orang di sekitar wilayah tersebut tidak menganggap itu sebagai tempat yang keramat. Hal tersebut memang bertentangan dengan ajaran Sapta Darma, tidak perlu menganggap suatu tempat sebagai tempat sakral dan diberi sesaji, para pemeluk ajaran Sapta Darma hanya memohon rizki, keselamatan, dan perlindungan hanya kepada Allah Hyang Maha Kuasa.

Perjalanan Panuntun Agung Sri Gutama terus berlanjut di beberapa wilayah, namun beliau kembali lagi ke Kabupaten Magetan setahun kemudian tepatnya 4 Februari 1958. Ajakan sujud kepada masyarakat Magetan kembali membuahkan hasil, dalam persinggahan tersebut pemeluk ajaran Sapta Darma menjadi sekitar 200 orang. Sri Gutama berada di Magetan selama 20 hari dan melanjutkan jalur persebarannya ke wilayah lainnya.

Dalam persebarannya di Kabupaten Magetan, Panuntun Agung Sri Gutama didampingi oleh Panuntun Wanita Sri Pawenang dan beberapa orang. Pemeluk ajaran Sapta Darma yang berhasil diajak untuk melakukan sujud adalah golongan orang-orang petani, pekerja kasar, atau lapisan masyarakat kelas menengah ke bawah. Hal tersebut dikarenakan hampir sebagian para pengikut Sapta Darma mau melaksanakan sujud setelah disembuhkan dari sakit oleh Panuntun Agung Sri Gutama ataupun Sri Pawenang. Sakit tersebut tidak bisa disembuhkan karena keterbatasan ekonomi sehingga mereka bersedia melaksanakan apapun asalkan bisa disembuhkan.

Dengan metode Sabda Usada Waras, para penderita sakit ini melaksanakan sujud dan memohon kesembuhan kepada Allah Hyang Maha Kuasa. Setelah itu Panuntun Agung Sri Gutama mengucapkan kata Waras 
kepada penderita sakit. Dan karena karunia Tuhan, sebagian besar orang-orang berhasil disembuhkan dari penyakitnya. Karena bukti kesembuhan itulah, orang-orang mengakui bahwa sapta Darma adalah ajaran yang bisa memberikan bukti nyata sehingga mereka memeluk ajaran Sapta Darma.

Panuntun Agung Sri Gutama meninggal dunia tanggal 16 Desember 1964. Kepemimpinan digantikan oleh Sri Pawenang dan semakin maju dalam perkembangannya. Hal tersebut diperkuat oleh keputusan pusat mengenai penggantian nama sesuai Penetapan Presiden tahun 1965 tentang penggantian nama Sapta Darma menjadi Kerohanian, sehingga memperkuat kedudukan Sapta Darma sebagai sebuah ajaran yang diakui oleh pemerintah. Di Magetan, pemeluknya semakin bertambah karena mereka mengetahui bahwa Sapta Darma merupakan ajaran yang tidak menyimpang dan tidak dilarang Pemerintah Indonesia.

\section{b) Periode Tahun 1967-1987}

Pada masa ini, kedudukan ajaran Sapta Darma di wilayah Kabupaten Magetan semakin kuat dan bertambah pemeluknya. Banyak pertemuan dan kunjungan dari Sri Pawenang di wilayah yang berdekatan dengan Magetan sehingga menguatkan keyakinan pemeluk Sapta Darma. Tercatat pada tahun 1977 Sri Pawenang mengadakan kunjungan ke Madiun di Balai Desa Oro-oro Ombo. Pada kesempatan itu, para warga Sapta Darma termasuk cabang Magetan mengikuti pertemuan sekaligus wejangan oleh Sri Pawenang. Dengan adanya pertemuan selama beberapa kali dalam periode ini jumlah pemeluknya bertambah. Hal itu karena secara langsung mereka bisa bertemu dengan Sri Pawenang sehingga menambah ketertarikan masyarakat Magetan untuk mendalami ajaran tersebut.

Pada masa tersebut juga mulai dikembangkan media penyebaran ajaran melalui buletin dan majalah ataupun media tulis secara umum dan menyebar luas di kalangan masyarakat termasuk warga Sapta Darma Cabang Magetan. Penerbitan majalah Sinar Cahya oleh Tuntunan Pusat di Yogyakarta mulai tahun 1972, menyebabkan tersebarnya berita-berita mengenai Sapta Darma ke seluruh wilayah. Bagi masyarakat Magetan ini juga membawa dampak terhadap jumlah pemeluk baru ajaran Sapta Darma.

\section{c) Periode tahun 1987-1997}

Selama satu dasawarsa ini, diterbitkan lagi buletin Klinting Semar yang memuat pula isi ajaran secara luas dan umum dapat diketahui masyarakat. Ini juga membawa perubahan dalam hal jumlah pemeluk Sapta Darma di Magetan. Jumlahnya bertambah dan ajaran ini semakin banyak diterima oleh masyarakat Magetan. Kepengurusan Persada Magetan juga terjadi perubahan dengan pengaktifan Tuntunan Persada dan juga Ketua Persada yang semakin sering mengadakan koordinasi dengan Persada di kabupaten 
lain untuk mengadakan pertemuan. Dengan itu semua maka persatuan antar warga semakin erat sehingga satu sama lainnya bisa menjalin hubungan untuk menjaga kerukunan. Karena itu pula ajakan untuk sujud bagi anggota baru semakin sering membuahkan hasil.

\section{d) Periode 1998-2011}

Pada masa modern seperti sekarang persebaran ajaran tidak hanya dilakukan melalui media cetak, namun telah merambah ke dunia internet dan media digital seperti web bahkan media jejaring sosial. Semakin mudah mengakses info dan berita-berita terkait aktifitas warga Sapta Darma di setiap Persada. Namun bagi Persada Magetan, masih belum memiliki akses yang mewadahi khusus kegiatan warga Sapta Darma melalui media internet. Walaupun sedikit disayangkan, hal tersebut tidak menghalangi untuk tetap melakukan kegiatan. Warga Persada Magetan tetap dapat mengakses informasi melalui internet untuk tambahan pengetahuan mengenai ajaran Sapta Darma itu sendiri.

Perkembangan Sapta Darma pada masa sekarang juga tidak lepas dari peran Sudarno sebagai Ketua Persada Sapta Darma. Beliau tinggal di Desa Sadon Panekan dan bekerja sebagai seorang Pegawai Negeri. Jabatan menjadi ketua telah di pegangnya selama kurang lebih lima tahun sampai sekarang. Menurutnya, pemeluk Sapta Darma memang tidak mengalami peningkatan secara besar, namun terus bertambah secara berkala setiap tahunnya. Mengenai jumlah pasti, tidak ada catatan atau pengarsipan terperinci sehingga agak sukar untuk memastikannya. Namun, orang-orang yang menjadi pemeluk Sapta Darma sudah pasti dikenalnya lewat pertemuan Jumat Wage

\section{Penutup}

\section{A. Simpulan}

Sebagai sebuah produk kebudayaan dalam bidang kepercayaan atau religi, Sapta Darma masih berkembang di berbagai wilayah di Indonesia, bahkan memiliki cabang di beberapa negara tetangga. Sekalipun merupakan aliran yang termuda, namun Sapta Darma tergolong sebagai sebuah kebatinan yang memiliki kejelasan sejarah dari awal penerimaan wahyu. Dalam sejarahnyapun, Panuntun Agung Sri Gutama dan Panuntun Agung Sri Pawenang adalah orang-orang yang turut memberikan sumbangsih bagi negara yang berasaskan Pancasila.

Di Kabupaten Magetan, sejak tahun 1957 hingga tahun 2011, jumlah pemeluk aliran Sapta Darma terus bertambah. Sekalipun tidak ada rincian pasti mengenai jumlah, namun tidak mengurangi makna dalam aktivitas dan eksistensi Sapta Darma di antara sekian banyaknya aliran kepercayaan yang turut pula ada di Magetan. Bagi pemeluk ajaran Sapta Darma, mereka lebih memusatkan orientasi mereka terhadap ketaatan menjalankan aturan 
dalam Wewarah Sapta Darma. Namun, mereka tetap dengan tangan terbuka, tanpa ajakan, tanpa paksaan akan menerima setiap anggota baru yang bersedia menjalankan ajaran Sujud, Racut dan segala macam peribadatan Sapta Darma tanpa memandang golongan manapun.

\section{B. Saran}

Berdasarkan dari hasil penelitian yang dilakukan beberapa saran yang dapat disampaikan adalah sebagai berikut:

\section{Bagi pemerintahan Kabupaten Magetan}

Melihat eksistensi Sapta Darma yang banyak dianut oleh masyarakat Magetan, hendaknya memberikan kebijakan terkait dengan pendataan pasti terhadap penghayat aliran kepercayaan yang berkembang dan ada di kabupaten Magetan. Hal tersebut akan memberikan manfaat dalam pemenuhan hak-hak setiap masyarakat di kabupaten Magetan.

\section{Bagi masyarakat Desa Milangasri}

Sebagai tempat berdirinya Gedung Persada Sapta Darma Cabang Magetan, perlu menjaga keharmonisan hubungan antar umat beragama dengan penghayat kepercayaan yang berada di wilayah tersebut. Untuk mewujudkan kerukunan dalam masyarakat.

\section{Bagi pemeluk Ajaran Sapta Darma Cabang Kabupaten Magetan}

Sebagai pemeluk aliran yang mengutamakan keharmonisan hubungan antar manusia, pemeluk Sapta Darma harus lebih bisa mengupayakan hubungan agar terjalin dengan baik dengan masyarakat di sekitarnya. Ini bertujuan untuk menjaga eksistensi aliran yang mereka yakini. Bagi pengurus Persada maupun pusat, penghitungan jumlah pasti pemeluk Sapta Darma juga penting demi terpenuhinya hakhak pemeluk Sapta Darma serta pengorganisasian yang lebih baik. Sehingga nantinya Sapta Darma akan terus berkembang demi mewujudkan manusiamanusia yang kuat rohaninya serta menjaga keharmonisan masyarakat. Penyesuaian teknik penyebaran ajaran juga perlu disesuaikan dengan perkembangan jaman sehingga bisa dilakukan dengan variasi yang lebih beragam, mislanya dengan media internet ataupun yang lainnya untuk mengikat persaudaraan dan hubungan antar pemeluk Sapta Darma di tingkat Persada Magetan.

\section{Daftar Pustaka}

Abraham Nur Cahyo Dkk.2008.Ilmu Sosial Dan Budaya Dasar.Magetan: Swastika

Abraham Nurcahyo. 2012. Ritual Larung Sesaji Telaga Ngebel Ponorogo. Madiun: Prodi Pendidikan Sejarah IKIP PGRI Madiun

BPS.2012. Kecamatan Panekan Dalam Angka. Magetan: BPS

Beatty, Andrew. 2001. Variasi Agama di Jawa. Jakarta: PT Raja Grafindo Persada 
Burhan Bungin.2005. Analisis Data Penelitian Kualitatif. Jakarta: PT Raja Grafindo Persada

Hartono Ahmad.2003. Bila Kyai Dipertuhankan. Jakarta: Al Kautsar

Harun Yahya.2004. Ancaman Dibalik Romantisisme. Bandung: Dzikra

H.B Sutopo. 2002. Metodologi Penelitian Kualitatif. Surakarta: Sebelas Maret University Press

Helius Sjamsudin,. 2007. Metodologi Sejarah. Yogyakarta: Ombak

Hilman Hadikusuma.1983. Antropologi Agama. Bandung: PT Citra Aditya Bakti

Imam Budhi Santosa.2010. Nasihat Hidup Orang Jawa.Yogyakarta: Diva Press 2012. Spiritualisme Jawa. Yogyakarta.: Memayu Publishing

Iskandar .2008. Metodologi Penelitian Pendidikan dan Sosial. Jakarta: Galang Persada Press

Kuntowijoyo.2001. Pengantar Ilmu Sejarah. Yogyakarta: Yayasan Bentang Budaya Hadari Nawawi. 2005. Metode Penelitian Bidang Sosial. Yogyakarta: Gadjah Mada University Press

2008. Penjelasan Sejarah. Yogyakarta: Tiara Wacana

Koentjaraningrat.1997. Manusia Dan Kebudayaan Di Indonesia. Jakarta: Karya Unipress

Miles dan Huberman.1992. Analisis Data Kualitatif. Jakarta: UI Press

Nana Syaodih.2007. Metode Penelitian Pendidikan. Bandung: Rosda Karya
Saefur Rochmat. 2009. Ilmu Sejarah dalam Perspektif Ilmu Sosial. Yogyakarta: Graha Ilmu

Smith, Huston. 2001. Agama-agama Manusia. Jakarta: Yayasan Obor Indonesia

Sugiyono. 2009. Metode Penelitian Kuantitatif, Kualitatif dan R\&D. Bandung: Alfabeta

Sutiyono.2010. Benturan Budaya Islam: Puritan dan Sinkretis. Jakarta: Penerbit Buku Kompas

Sri Pawenang dkk. 2010. Sejarah Penerimaan Wahyu Wewarah Sapta Darma dan Perjalanan Panuntun Agung Sri Gutama. Yogyakarta: Sekertariat Tuntunan

Suwardi Endraswara.2011. Kebatinan Jawa dan Jagad Mistik Kejawen. Yogyakarta: Lembu Jawa

Suwardi Endraswara.2010. Falsafah Hidup Jawa. Yogyakarta: Cakrawala

Internet:

http://blogkejawen.blogspot.com/2011/03 Laliran-kerohanian-saptadarma.html, Di unduh 28 Juli 2013 http://sapta-darma.info/sejarah.html, di unduh 28 Juli 2013 